\title{
The Empirical Study of Association of Capital Structure and Profitability of Telecommunication Firms
}

\author{
Avani Raval and Ashvin Dave \\ ${ }^{1}$ Department of Business Administration and Commerce, School of Liberal Studies, \\ Pandit Deendayal Energy University, Raisan, Gandhinagar, Gujarat, India. \\ Corresponding author email: avaniraval04@gmail.com
}

\section{ABSTRACT}

The study tries to evaluate the capital structure practices carried out by Tele Communication companies listed on BSE/ NSE. Debt equity ratio, Interest coverage ratio, current ratio as independent and return on net worth as dependent are the selected variables undertaken for the study. The study tries to undertake the data evaluation of selected variables for the tenure of ten years i.e. 2010-2019. The author used descriptive, regression and co-efficient of correlation for analysis. The research indicates that there is debt equity ratio has significantly positive relationship with profitability and Interest coverage ratio; current ratio has insignificantly positive relationship with profitability.

KEY WORDS: CAPITAL STRUCTURE, RETURN ON NET WORTH.

\section{INTRODUCTION}

Capital is huge part of the corporate activities, which are determined by the nature of the firm and size. Capital will increased by the difference sources. If the firm manage the capital structure very well, then it will increase huge profit of the firm and they will able to give dividends to their shareholders. Equity and debt are sources of finance for corporate company. Marketing is huge problem of capital structure for the particular company. It is basically worried about how the company chooses to partition its cash flow into two expansive segments, a fixed segment that is reserved to meet the commitments toward obligation capital and a leftover segment that has a place with value investors. Capital structure should be observed that it is effect on value of the company. If the capital structure can influence on value of the firm, then increase its market value. Though, capital structure is contradictory theories on the association with the value

Biosc Biotech Res Comm P-ISSN: 0974-6455 E-ISSN: 2321-4007

\section{crossef}

Identifiers and Pagination

Year: 2021 Vol: 14 No (5) Special Issue

Pages: 190-193

This is an open access article under Creative

Commons License Attribn 4.0 Intl (CC-BY).

DOI: http://dx.doi.org/10.21786/bbrc/14.5/34 of firm. The conservatives trust that capital structure influence the firm's value but there are some many differences of the traditional theory. In the capital market has no tax and argue that capital structure result is not significant. Modigliani and Miller inverse their place when they consider business firm taxes.

Litrature Rivew: Dr. R. kavitha (2014) analysed the 21 firms over a time period of ten years with span of 200203 to 2011-12 has been taken for analysis pharmaceutical firms. They had taken financial leverage as dependent variable and size of firm, business risk, liquidity, earning rate, tangible, debt service capacity, non-debt tax shield and degree of operating leverage as independent variable. Research used Karl Pearson's correlation, descriptive statistics, and regression coefficient for analysis. It was notice that factors are significantly affect to the financial leverage in these firm and insignificantly affect the risk, liquidity, non-debttax shield and degree of operating leverage.

Jana Stekla, Marta Grycova (2016) analysed the 1572 firms over a time period of six years with span of 2009 to 2013 has been taken for analysis in agriculture holding companies. They had taken short term debt to total assets, long term debt to total assets, total debt to total assets, sale growth and firm size as independent variable and
Article Information

Received: $26^{\text {th }}$ Jan 2021

Accepted after revision: $27^{\text {th }}$ Mar 2021 
return on equity as dependent variable. They were using descriptive statistics, correlation analysis and regression analysis. the result indicating that there is adverse association among short term debt to total assets, long term debt to total assets, total debt to total assets and return on equity.

Sujeewa Kodithuwakku (2018) analysed the performance of ten Regional Plantation firm for a period of 7 years i.e. 2009 to 2015. The components considered are total debt to equity, debt to total assets and interest coverage ratio. Researcher used descriptive statistics and Ordinary Least Squire regression model. It was notice that the debt to equity ratio has negative association with share price. Further notice that the interest coverage ratio has positive association with share price. It was point out that there insignificance influence between the debt to total assets and share price. Narinder Pal Singh, Mahima Bagga (2019) the study has been evaluates the 50 nifty firms registered on NSC for the period of ten year i.e. 2008 to 2017. They had taken return on assets and return on equity as dependent variables and total liabilities to total assets and total equity to total assets. They used descriptive statistics, correlation and multiple panel data regression models for analysis. They studied the separate impact of the total debt and total equity ratios on return on assets and return on equity. It was concluded that there is positively important effect of company's profitability.

Ms. Shireen Rosario and Dr Kavita Chavali (2019) analysed the performance of 22 firms over a time period of 12 years with the span of 2006 to 2017 has been taken for analysis in hotel industry in India. They had taken debt to equity ratio as dependent variable and net profit, return on capital employed, return on equity, return on assets, interest coverage, debt to total assets, short term debt to total assets and long term debt to total assets as independent variables. They were using descriptive statistics and correlation analysis. Results are indicating that debt variable has positive relationship with profit. It was point out that there is also negative relation between debt variables and rest of the other variable. Juan Gallegos Mardones and Gonzalo Ruiz Cuneo (2020) analysed the ownership structure of public firm over a time period of ten years i.e. 2005 to 2015. The variables consider are Return on assets, Return on equity, Tobin's Q, Short-term debt, Long-term debt, Growth, Size, Tangibility, Tax, Operational risk, Capital expenditure, Cash , Profitability, Liquidity, Paid dividend. They were using descriptive statistics and regression analysis. It was found that size of the firm has positively association with financial performance and growth. Further found that there is mixed outcome for firm liquidity, as well as long term and short term financial leverage.

Yarong Chen, Davide Migliaro \& Juliana Silva (2021) in their study a sample of 136 SMEs in Brazilian context for a period of three years i.e. 2016 to 2018. The variables consider are total debt, firm age, assets tangibility, profitability, turnover growth and size. They used panel data analysis and ordinary least squares regression model to check relationship of all variables with profitability. The result shows that there is adverse association among age and profitability with debt. It was notice that there is positive association among assets tangible, growth and size with debt.

Adepoju Adeoba Asaolu (2021) analysed the performance of two sectors for ten years with the span of 2010 to 2019. The variables consider are total assets, equity, return on assets, return on equity, leverage, firm size, assets tangibility, Non Debt tax shield, dividend growth, director's share and interest payment. Researcher used descriptive analysis, correlation matrix and panel unit test. It is notice that there is positive association and showing that these component tend to influence company show on the on the average across both areas. Hariem Abdullah, Turgut Tursoy (2021) studied 102 companies for twenty four years with the span of 1993 to 2016. They had taken leverage ratio, return on assets, stock price and control as component. They were using descriptive statistics, correlation analysis and regression analysis. Point out that there is positively association among financial leverage and financial performance. It was notice that market performance and capital structure can negative influence with each other. Further notice that stock price and leverage ratio has negative impact with each other.

\section{RESEARCH METHODOLOGY}

- The main objective of study is to understand the relationship between dependent and independent variables i.e. capital structure and profitability of the telecommunication firms. For this purpose fourteen leading BSC and NSC listed firms have been selected on debt equity ratio (DER), interest coverage ratio (ICR), current ratio (CR) as independent variables and return on net worth (RONW) as dependent variable. The selected 14 firms are ATC Infrastructure Services Pvt Ltd, Bharti Airtel Ltd, Bharti Hexacom Ltd, Indus Towers Ltd, Mahanagar Telephone Nigam Ltd, Nettlinx Ltd, OnMobile Global Ltd, Quadrant Televentures Ltd, Railtel Corporation of India Ltd, Reliance Communications Ltd, Tata Communications Ltd, Tata Teleservices (Maharashtra) Ltd, Tatanet Services Ltd and Vodafone Idea Ltd. The data has been collected from CAPITALINE database. Annual report of the firms with the span of ten year viz. 2010 to 2019 and firms were analysed by using descriptive, ANOVA, coefficient and correlation.

\section{- Hypothesis}

H0: DER has positive relation with RONW

H1: DER has no positive relation with RONW

Ho: ICR has positive relation with RONW

H1: ICR has no positive relation with RONW

Ho: CR has positive relation with RONW 
H1: CR has no positive relation with RONW

\section{Analysis}

1. Table - I presented the variables of descriptive statistics. The outcomes presented this studied will be more appropriate to the firms whose data sets resemble the descriptive method indicate in Table $-\mathrm{I}$.

2. Table - II presented that the multi co linearity between independent variables i.e. CR, ICR, DER have been considered by karl-person coefficient of correlation besides Table III consider the VIF statistic. It is accurately shows that all component of co-efficient of correlations' value has not more than +0.1 and VIF statistics not close to 10. Therefore the difficultly of multi co linearity does not occur amongst the independent component.

3. Table - III presented the regression coefficient. It is indicating that direction, standardized Beta, significance level, values and VIF are mention in Table - III. Table - III shows that debt equity ratio, interest coverage ratio, current ratio as independent variables has association with return on net worth. The $\beta$ of debt equity ratio as presented in Table III, stands at +0.953 viz. indicate that debt equity ratio has positive relationship with return on net worth. The value of significance level is 0.0000. it is clearly notice that the significance coefficient beta $(\beta)$ is statistically very significant. Therefore null hypothesis (DER) be accepted and H1 be rejected.

4. Table - III considered the value of interest coverage ratio i.e. 0.013 it is revel that $\beta$ has positive relationship with return on net worth. The value of significance level is 0.631 it means $\beta$ is statistically insignificant. Therefore null hypothesis (ICR) be accepted and $\mathrm{H} 1$ be rejected.

5. The $\beta$ of current ratio as presented in Table - III, stands at +0.014 viz. indicate that current ratio has positive relationship with return on net worth. The value of significance level is 0.573 . It is clearly notice that the significance coefficient beta $(\beta)$ is statistically not relevant. Therefore null hypothesis (CR) be accepted and $\mathrm{H} 1$ be rejected.

\begin{tabular}{|c|c|c|c|c|}
\hline Variables $\rightarrow$ & RONW & DER & ICR & CR \\
\hline Mean & 17.5219 & 4.5226 & 8.7167 & 0.9456 \\
\hline Std. Deviation & 93.98246 & 30.19685 & 280.49766 & 1.13297 \\
\hline
\end{tabular}

\begin{tabular}{|l|c|c|c|}
\hline \multicolumn{4}{|c|}{ Table 2. Matrix of Co-efficients of Correlations } \\
\hline & CR & ICR & DER \\
\hline CR & 1.000 & -0.073 & 0.111 \\
\hline ICR & -0.073 & 1.000 & -0.491 \\
\hline DER & 0.111 & -0.491 & 1.000 \\
\hline
\end{tabular}

Table 3. Regression Co-efficients

\begin{tabular}{|c|c|c|c|c|c|}
\hline \multirow{2}{*}{} & \multicolumn{2}{|l|}{$\begin{array}{l}\text { Regression } \\
\text { Co-efficients }\end{array}$} & \multirow{2}{*}{ Significance Level } & VIF \\
\cline { 2 - 4 } & Direction & Value & & & \\
\hline Constant & & $\mathbf{2 . 9 7 9}$ & & & \\
\hline DER & + & $\mathbf{0 . 9 5 3}$ & $\mathbf{3 3 . 9 1 7}$ & $\mathbf{0 . 0 0 0}$ & $\mathbf{1 . 3 2 7}$ \\
\hline ICR & + & $\mathbf{0 . 0 1 3}$ & $\mathbf{0 . 4 8 1}$ & $\mathbf{0 . 6 3 1}$ & $\mathbf{1 . 3 1 7}$ \\
\hline CR & + & $\mathbf{0 . 0 1 4}$ & $\mathbf{0 . 5 6 5}$ & $\mathbf{0 . 5 7 3}$ & $\mathbf{1 . 0 1 3}$ \\
\hline \\
$\begin{array}{l}\text { Dependent Variable : RONW } \\
\text { Independent Variables: DER, ICR, CR }\end{array}$ \\
\hline
\end{tabular}

\section{- Findings and Recommendation}

1. It is find that there is significantly positive association among debt equity ratio and return on net worth and the significance coefficient beta $(\beta)$ is statistically very important. This means companies must devote is a significant variable effect the profitability.

2. Further find that interest coverage ratio has positive relationship with return on net worth and the significance coefficient beta $(\beta)$ is statistically 
not relevant. It recommended that firm should not allocate more important to interest coverage ratio.

3. The current ratio has positive association with profitability and significance coefficient beta is statistically insignificant. It recommended that company do not devote is important component effect the profitability.

\section{CONCLUSION}

The research disclosed relationship between capital structure and profitability that there is positive association between debt equity ratio, Interest coverage ratio, current ratio and return on net worth. The result shows that only one variable has significantly positive relation among debt equity ratio and return on net worth and rest of two variable viz. interest coverage ratio and current ratio has insignificantly positive relation with return on net worth.

\section{REFRENCES}

Asaolu, A. A. (2021). Capital Structure and Firm Performance: A comparative Study of Oil \&t Gas and Manufacturing Sectors in the United States of America. Business and Management Studies, 7(1), 29-44.

Cuneo, J. G. (2020). Capital structure and performance in Latin American companies. ECONOMIC RESEARCHEKONOMSKA ISTRAŽIVANJA, 33(1), 2171-2188.
Hariem Abdullah, T. T. (2021). Capital structure and firm performance: a panel causality test. Munich Personal RePEc Archive, 1-19.

Jana STEKLA, M. G. (2016). The relationship between profitability and capital structure of the agricultural holdings in the Czech Republic. Agric. Econ. - Czech, 62(9), 421-428.

Kodithuwakku, S. (2018). IMPACT OF CAPITAL STRUCTURE ON SHARE PRICES WITH SPECIAL REFERENCE TO THE PLANTATION SECTOR IN SRI LANKA. International Journal of Development Research, 8(9), 23100-23105.

Ms. Shireen Rosario, D. K. (2019). CAPITAL STRUCTURE AND ITS IMPACT ON PROFITABILITY - A STUDY OF INDIAN HOTEL INDUSTRY. International Journal of Business and Administration Research , 6(1), 67-72.

Narinder Pal Singh, M. B. (2019). The Effect of Capital Structure on Profitability: An Empirical Panel Data Study. Jindal Journal of Business Research, 8(1), 6577.

R.Kavitha, D. (2014). Determinants of Capital Structure: Emprical Evidence from India. INDIAN JOURNAL OF APPLIED RESEARCH, 4(7), 305-309.

Yarong Chen, D. M. (2021). Capital Structure Determinants of SMEs: Empirical Evidence. IAR J Bus Mng, 2(1), 180-186. 